\title{
Muscle Metabolic Modulation by Chronic Hypoxia
}

Citation for published version (APA):

Gosker, H. R., \& Schols, A. M. (2007). Muscle Metabolic Modulation by Chronic Hypoxia. Journal of Proteome Research, 6(9), 3400-3401. https://doi.org/10.1021/pr070315e

Document status and date:

Published: 01/01/2007

DOI:

10.1021/pr070315e

Document Version:

Publisher's PDF, also known as Version of record

Document license:

Taverne

Please check the document version of this publication:

- A submitted manuscript is the version of the article upon submission and before peer-review. There can be important differences between the submitted version and the official published version of record.

People interested in the research are advised to contact the author for the final version of the publication, or visit the DOI to the publisher's website.

- The final author version and the galley proof are versions of the publication after peer review.

- The final published version features the final layout of the paper including the volume, issue and page numbers.

Link to publication

\footnotetext{
General rights rights.

- You may freely distribute the URL identifying the publication in the public portal. please follow below link for the End User Agreement:

www.umlib.nl/taverne-license

Take down policy

If you believe that this document breaches copyright please contact us at:

repository@maastrichtuniversity.nl

providing details and we will investigate your claim.
}

Copyright and moral rights for the publications made accessible in the public portal are retained by the authors and/or other copyright owners and it is a condition of accessing publications that users recognise and abide by the legal requirements associated with these

- Users may download and print one copy of any publication from the public portal for the purpose of private study or research.

- You may not further distribute the material or use it for any profit-making activity or commercial gain

If the publication is distributed under the terms of Article $25 \mathrm{fa}$ of the Dutch Copyright Act, indicated by the "Taverne" license above, 


\title{
communications piregerteome
}

\section{Muscle Metabolic Modulation by Chronic Hypoxia}

\author{
Harry R. Gosker* and Annemie M. W. J. Schols \\ Department of Respiratory Medicine, Nutrition and Toxicology Research Institute Maastricht (NUTRIM), \\ Maastricht University, P.O. Box 616, 6200 MD Maastricht, The Netherlands
}

Received May 25, 2007

\begin{abstract}
De Palma et al. published a research paper in which they describe the effect of chronic hypoxia on rat skeletal muscle metabolism by means of a comparative proteomic analysis (J. Proteome Res. 2007, 6(5), 19741984). For this, relatively young animals were used. In our communication, we note that, based on other literature, it is likely that the adaptive response of skeletal muscle to hypoxia attenuates with age.
\end{abstract}

Keywords: skeletal muscles - hypoxia - muscle fiber types • energy metabolism - hypoxia inducible factor $1 \alpha$ (HIF1 $\alpha$ )

In the May issue of this year, De Palma et al. published a research paper in which they describe the effect of chronic hypoxia on rat skeletal muscle metabolism by means of a comparative proteomic analysis. ${ }^{1}$ Their results comply with what is regarded as the "Pasteur effect": a hypoxia-induced shifting from oxidative toward glycolytic metabolism. ${ }^{2}$ The authors state that muscle tissue provides a good model of in vivo hypoxia adaptation. This is probably true, but the conditions under which the muscle tissue is exposed to hypoxia should not be overlooked. For example, hypoxia causes very distinct muscular adaptations when muscles are simultaneously exercised as compared to non-exercised muscles. ${ }^{3}$ The adaptive response to hypoxia may also differ between postnatal developing and matured muscles. Indeed, hypoxia-induced fiber type I to II shifts have been observed in young (3-week old) rats ${ }^{4}$ but not in adult (10-week old) rats. ${ }^{5}$ This is quite a consistent finding, and therefore Ishihara et al. postulated that chronic hypoxia inhibits the growth-related II to I fiber type shift that occurs during normal musculoskeletal development. ${ }^{6}$ In growing postnatal muscles, satellite cells (myogenic stem cells) become myoblasts that differentiate and fuse with existing myofibers. There are indications that type II myosin heavy chain isoform is expressed by "default" and that depending on various external stimuli, expression shifts toward the type I myosin heavy chain isoform. ${ }^{7}$ Because type I fibers are more oxidative as compared to type II fibers, the growth-related increase in protein levels associated with oxidative metabolism is likely also inhibited by hypoxia exposure. Many genes encoding for the enzymes involved in glycolytic metabolism

* To whom correspondence should be addressed. H.R. Gosker, Department of Respiratory Medicine, Maastricht University, Nutrition and Toxicology Research Institute Maastricht, P.O. Box 616, 6200 MD Maastricht, The Netherlands; Telephone number, +31-43-3884247; Fax number, +31-433875051; E-mail, H.Gosker@pul.unimaas.nl.

3400 Journal of Proteome Research 2007, 6, 3400-3401 Published on Web 07/20/2007 are under the transcriptional control of the hypoxia inducible factor $1 \alpha(H I F 1 \alpha)$ (for review, see ref 8 ), which was also found to be upregulated by De Palma et al. Interestingly, muscular angiogenesis in response to hypoxia is also impaired with aging as the result of reduced DNA binding of HIFl $\alpha$ and the subsequent downregulation of its target gene vascular endothelial growth factor. ${ }^{9,10}$ De Palma et al. studied 5-week old rats, which can be considered as relatively young animals whose muscles are still developing and in which hypoxia may have inhibited the shift from type II toward the more oxidative type I phenotype. It is not unlikely that the observed muscle metabolic modulation will be less pronounced in older rats with full-grown muscles when being exposed to hypoxia. This is a very intriguing question that deserves more attention. It is also interesting from a pathological point of view. Loss of muscle oxidative phenotype is common in disorders such as chronic obstructive pulmonary disease and chronic heart failure. ${ }^{11}$ Muscle hypoxia is a potential cause, but it is unclear in what phase (satellite cell, myoblast, myofiber) skeletal muscle cells are most responsive to hypoxia in exhibiting the Pasteur effect. The comparative proteomic analysis used by the De Palma et al. would provide just the right tool to shed more light on this matter.

Acknowledgment. The research of H.R.G. was supported by an award from the Netherlands Asthma Foundation (project number 3.2.05.038).

\section{References}

(1) De Palma, S.; Ripamonti, M.; Vigano, A.; Moriggi, M.; Capitanio, D.; Samaja, M.; Milano, G.; Cerretelli, P.; Wait, R.; Gelfi, C. Metabolic Modulation Induced by Chronic Hypoxia in Rats Using a Comparative Proteomic Analysis of Skeletal Muscle Tissue. J. Proteome Res. 2007, 6(5), 1974-1984.

(2) Seagroves, T. N.; Ryan, H. E.; Lu, H.; Wouters, B. G.; Knapp, M.; Thibault, P.; Laderoute, K.; Johnson, R. S. Transcription factor HIF-1 is a necessary mediator of the pasteur effect in mammalian cells. Mol. Cell. Biol. 2001, 21(10), 3436-3444.

(3) Hoppeler, H.; Vogt, M. Muscle tissue adaptations to hypoxia. J. Exp. Biol. 2001, 204(Pt 18), 3133-3139.

(4) Itoh, K.; Itoh, M.; Ishihara, A.; Hirofuji, C.; Hayashi, H. Influence of 12 weeks of hypobaric hypoxia on fibre type composition of the rat soleus muscle. Acta Physiol. Scand. 1995, 154(3), 417418.

(5) Takahashi, H.; Kikuchi, K.; Nakayama, H. Effect of chronic hypoxia on skeletal muscle fiber type in adult male rats. Ann. Physiol. Anthropol. 1992, 11(6), 625-630.

(6) Ishihara, A.; Itoh, K.; Itoh, M.; Hirofuji, C. Effect of hypobaric hypoxia on rat soleus muscle fibers and their innervating motoneurons: a review. Jpn. J. Physiol. 2000, 50(6), 561568.

10.1021/pr070315e CCC: $\$ 37.00$ @ 2007 American Chemical Society 
(7) Schiaffino, S.; Reggiani, C. Molecular diversity of myofibrillar proteins: gene regulation and functional significance. Physiol. Rev. 1996, 76(2), 371-423.

(8) Semenza, G. Signal transduction to hypoxia-inducible factor 1. Biochem. Pharmacol. 2002, 64(5-6), 993-998.

(9) Rivard, A.; Berthou-Soulie, L.; Principe, N.; Kearney, M.; Curry, C.; Branellec, D.; Semenza, G. L.; Isner, J. M. Age-dependent defect in vascular endothelial growth factor expression is associated with reduced hypoxia-inducible factor 1 activity. J. Biol. Chem. 2000, 275(38), 29643-29647.
(10) Rivard, A.; Fabre, J. E.; Silver, M.; Chen, D.; Murohara, T.; Kearney, M.; Magner, M.; Asahara, T.; Isner, J. M. Age-dependent impairment of angiogenesis. Circulation 1999, 99(1), 111-120.

(11) Gosker, H. R.; Wouters, E. F.; van der Vusse, G. J.; Schols, A. M. Skeletal muscle dysfunction in chronic obstructive pulmonary disease and chronic heart failure: underlying mechanisms and therapy perspectives. Am. J. Clin. Nutr. 2000, 71(5), 10331047

PR070315E 